\title{
A TÖNKÖLYBÚZA (TRITICUM SPELTA L.) ELEMFELVÉTELE SZENNYVÍZÜLEDÉKBÖL
}

\author{
Uri Zsuzsanna - Simon László - Vigh Szabolcs -Vincze György - \\ Irinyiné Oláh Katalin
}

\begin{abstract}
Absztrakt: Fényszobás tenyészedényes kísérletet állítottunk be a Nyíregyházi Egyetemen a Debrecen Lovász-zugból származó, toxikus elemekkel (elsősorban krómmal) szennyezett talajjal (mely egy szennyvíz utóülepítő tó rekultivációja során felhasznált talajtakaró volt), illetve kadmiumot, krómot, rezet, nikkelt, ólmot és cinket a határértékek felett tartalmazó Debrecen lovász-zugi szennyvízüledékkel. Kísérletünk célja az volt, hogy a környezeti stressz-faktorok iránt toleránsnak feltételezett lágy szárú növényfaj, a tönkölybúza (Triticum spelta L.) tenyészedényekben történő termesztésével, modell-kísérlettel megismerjük és összehasonlítsuk e növényfaj két vonalának (cv. GK Fehér "A"; cv. GK Fehér "B") táp- és toxikuselem-felvételi interakcióit a talajjal, illetve a szennyvízüledékkel $(10 \% \mathrm{~m} / \mathrm{m})$ kevert talajjal. 52 napos növénynevelést követően megállapítottuk, hogy a szennyvízüledék a kontrollhoz viszonyítva jelentősen megemelte mind a gyökerekben, mind a hajtásokban a foszfor-, kálium-, kalcium-, magnézium-, és nátriumkoncentrációkat mindkét tönkölybúza vonal esetén. A vizsgált makroelemek - a kalcium és a nátrium kivételével - a tönkölybúza hajtásában nagyobb mennyiségben voltak kimutathatóak, mint a gyökérében. A szennyvízüledék mindkét tönkölybúza vonal gyökereiben és hajtásaiban egyaránt megemelte az esszenciális mikroelemek $(\mathrm{Cu}, \mathrm{Fe}, \mathrm{Mn}, \mathrm{Zn})$ koncentrációit a kontrollhoz viszonyítva. A tönkölybúza toxikuselem-felvételét ( $\mathrm{As}, \mathrm{Ba}, \mathrm{Cd}, \mathrm{Cr}, \mathrm{Ni}, \mathrm{Pb}$ ) elemezve megállapítható, hogy a gyökerekben lényegesen több halmozódott fel a hajtásokhoz képest, és a kijuttatott szennyvízüledék valamennyi toxikus elem koncentrációját jelentősen megnövelte a kontroll kultúrákhoz viszonyítva, mind a gyökerekben, mind a hajtásokban. Nem tudtuk azonban igazolni, hogy a nemesítők által szenzitívebbnek feltételezett GK Fehér tönkölybúza fajta „A” vonala érzékenyebben reagál a toxikuselem-szennyezés okozta stresszre, illetve több toxikus elemet vesz fel, mint a toleránsabbnak tekintett „B” vonal.
\end{abstract}

Abstract: Uptake of various mineral nutrients and accumulation of toxic elements was studied in spelt (Triticum spelta $\mathrm{L}$. lines „A” and „B”) from a soil moderately contaminated with toxic elements (prevalently with chromium; 111-128 $\mathrm{mg} / \mathrm{kg}$ ), and from a sewage sediment contaminated with cadmium (1.27 mg/kg), chromium (1027 mg/kg), copper (189 mg/kg), nickel (49.5 mg/kg), lead (287 $\mathrm{mg} / \mathrm{kg})$, and zinc $(888 \mathrm{mg} / \mathrm{kg})$. Contaminated cover soil and sewage sediment originated from Debrecen Lovász-zug, Hungary $\left(47^{0} 29^{\prime} 000\right.$ ' ' N, 21035'738' E), from a former wastewater postsettling pond. Spelt was grown in a pot experiment for 52 days in a growth chamber, in cover soil (as a control) and in cover soil treated with $10 \%(\mathrm{~m} / \mathrm{m})$ sewage sediment. It was found that application of sewage sediment significantly enhanced the uptake of macro- and mezoelements $(\mathrm{P}, \mathrm{K}, \mathrm{Ca}, \mathrm{Mg}$, $\mathrm{Na}$ ), and essential microelements $(\mathrm{Cu}, \mathrm{Fe}, \mathrm{Mn}, \mathrm{Zn})$ both in roots and shoots of spelt. Toxic elements (As, $\mathrm{Ba}, \mathrm{Cd}, \mathrm{Cr}, \mathrm{Ni}, \mathrm{Pb}$ ) accumulated prevalently in the roots of plants, and the applied sewage sediment significantly increased their concentration in roots and shoots, as compared to the control cultures. Breeders supposed line „A” of spelt to be more sensitive for abiotic stresses (e.g. toxic element contamination) than line "B". This hypothesis, however, was not confirmed by our observations.

Kulcsszavak: elemfelvétel, szennyvízüledék, tönkölybúza, Triticum spelta L.

Keywords: mineral nutrients, toxic elements, spelt, Triticum spelta L., sewage sediment 


\section{Bevezetés}

Az ipari forradalom óta eltelt időszakban az intenzív fémhasznosítás eredményeként többszörösére nőtt a természetes vizek és talajok toxikuselem-szennyezettsége, és megváltozott a fémek biogeokémiai ciklusa. A mezőgazdasági hasznosítású és a „városi” talajok toxikuselem-szennyezettsége föként olyan antropogén tevékenységek eredményének tekinthető, mint a bányászat, kohászat, peszticidhasználat, fosszilis energiahordozók elégetése, közlekedés, hadászati célú anyagok gyártása és raktározása és a hulladékok deponálása (Adriano, 2001; Alloway, 2013; Kabata-Pendias, 2011; Simon, 2014).

A toxikus elemek talajban való felhalmozódása az összes érintett élőlény számára veszélyes. A toxikus elemek, nehézfémek képesek helyettesíteni az esszenciális fémek ionjait az enzimek vagy a pigmentek molekuláiban, amely eredményeként azok nem képesek megfelelően funkcionálni. A toxikus elemek hosszú távú expozíciója krónikus elváltozásokat okoz, illetve a mérgező fémek bekerülnek a táplálékláncba, veszélyeztetve a növényeken kívül az állatok és az emberek egészségét is. Ha a humán szervezet tartósan toxikuselem-hatásnak (ólom, kadmium, arzén) van kitéve, egészségkárosodás kialakulásának veszélye áll fenn, amely érintheti a bőrt, a májat és a vesét, a gasztrointesztinális rendszert, a központi idegrendszert, és mindezek mellett a mentális retardáció jelei is megfigyelhetők (Kabata-Pendias-Mukherjee, 2007; Babula et al., 2008).

A talajok fölös toxikuselem-tartalma mérgező hatást gyakorol a növényekre. A növények gyökerei abszorbeálják a fémek ionjait a talajból, elöbb a gyökerek, majd (függően a toxikus elem kémiai tulajdonságaitól) a föld feletti hajtások szöveteiben, és gátolják azok növekedését az anyagcsere-folyamatok limitációján keresztül. A talajokban megnövekvő toxikuselem-koncentráció csökkenti a talajok termékenységét, a mezőgazdasági hozamokat és a talajok mikrobiális közösségeinek aktivitását (Alloway, 2013; Kabata-Pendias, 2004).

A termesztett gabonafélék által egyik legáltalánosabban akkumulált szennyező nehézféme a kadmium, amely gátolja a gyökerek és a hajtások növekedését, csökkenti a tápelem-felvételt, és megbontja az elem-homeosztázis egyensúlyát. Mivel cereáliákat haszonállatainkkal együtt naponta fogyasztunk, a szennyezett mezőgazdasági termékeket elfogyasztó organizmusok egészségkárosodást szenvedhetnek (Slepecka et al., 2017; Kabata-Pendias, 2011; Kabata-PendiasMukherjee, 2007).

Fenti elözmények ismeretében célunk az volt, hogy tenyészedényes modellkísérletben vizsgáljuk meg a tönkölybúza szerveinek elemfelvételét egy toxikus elemekkel (elsősorban krómmal) enyhén szennyezett talajból, illetve kadmiumot, krómot, rezet, nikkelt, ólmot és cinket a határértékek felett tartalmazó szennyvízüledékből. Feltételeztük, hogy különbségek alakulnak ki a tönkölybúza egymástól különböző vonalainak elemfelvételében, ill. toxikuselem-toleranciájában. 


\section{Anyag és módszer}

A tenyészedényes kísérletünkhöz felhasznált talaj egy - korábbi időszakban - a szennyvíz oxidációjára, utóülepítésére, szikkasztására szolgáló lagúnarendszer rekultivációja során felhasznált talajtakaró Debrecen Lovász-zugból (47029'000' 'É, 21035'738' K), melyben a króm- és kadmiumkoncentrációk (Tözsér, 2018) meghaladják a 6/2009. (IV.14.) KvVM-EüM-FVM együttes rendeletben lefektetett határértékeket. A talaj genetikai típusa nem határozható meg.

2017 októberében egy 2,5x2,5 méteres Debrecen lovász-zugi mintavételi területről mintegy 350-400 kilogrammnyi feltalajt gyüjtöttünk össze ásónyomnyi mélységből, melyet a Nyíregyházi Egyetemen megszárítottunk, és 2 mm-es szitán átbocsátottunk. A megmintázott talajtakaró sötétszürke, antracit színü szennyvízüledéket fedett el, mintegy 70-75 cm-es mélységben. Ezt az anyagot is megmintáztuk, megszárítottuk és $5 \mathrm{~mm}$ lyukátméröjü szitán átbocsátottuk. Mindkét anyagból 25-25 leszúrással 3, illetve 4 ismétléssel kevert mintákat vettünk, majd elemanalízisre átszállítottuk a Debreceni Egyetem Agrármüszerközpontjába.

Tesztnövényként tönkölybúzát (Triticum spelta L.) alkalmaztunk, a nemesítök a GK Fehér DH „A” vonalát az abiotikus stresszt okozó tényezőkre szenzitívebbnek, „B" vonalát pedig toleránsabbnak feltételezték.

2018 márciusában $6 \mathrm{db} 16 \mathrm{~cm}$ átméröjü és $12,5 \mathrm{~cm}$ magas mủanyag tenyészedényt töltöttünk meg 1500-1500 gramm légszáraz kontroll talajjal, illetve 6 db ugyanolyan tenyészedényt töltöttünk meg légszáraz kontroll talaj és $10 \mathrm{~m} / \mathrm{m} \%$ légszáraz szennyvízüledék keverékével. A talaj 21\%-os szántóföldi vízkapacitása $75 \%$-nak megfelelő mennyiségü desztillált vízzel $33 \mathrm{mg} / \mathrm{kg}$ foszfort és $42 \mathrm{mg} / \mathrm{kg}$ káliumot juttatunk ki a talajba $\mathrm{KH}_{2} \mathrm{PO}_{4}$ oldat, illetve $40 \mathrm{mg} / \mathrm{kg}$ nitrogént juttattunk ki $\mathrm{NH}_{4} \mathrm{NO}_{3}$ oldat formájában. Ezt követően 16 héten át hetente egyszer desztillált vízzel telítettük a talajt, hogy a talajélet elinduljon, a szennyvízüledék a talajjal összeérjen, illetve a szennyvízüledék ásványosodjon.

2018 júniusában a tönkölybúza szemeket kicsíráztattuk (desztillált víz - csapvíz $1: 1 \mathrm{v} / \mathrm{v}$ elegyében szürőpapíron $12 \mathrm{~cm}$ átmérőjü Petri-csészékben), a kihajtott csíranövényekböl 6-6 darabot ültettünk el a 12 tenyészedény talajába. A tenyészedényeket ezután vernalizációs célból hidegszobába helyeztük, ahol +5 ..+9 ${ }^{0} \mathrm{C}$-on napi 8 órán át 3000 lux megvilágítást kaptak a növények, melyet fluoreszcens fénycsövekkel biztosítottuk. A növényeket hetente 2 vagy 3 alkalommal adott tömegig (1850 g) öntöztük desztillált vízzel. Három hetes vernalizáció után a növényeket áthelyeztük a fényszobába, ahol a hőmérséklet nappal $+21 \ldots+22{ }^{\circ} \mathrm{C}$, éjszaka pedig $+17 \ldots+18{ }^{\circ} \mathrm{C}$ között változott. A növények ekkor átlagosan $15 \mathrm{~cm}$ hosszúak voltak. A fényszobában a növényeket napi 12 órán át (reggel 6-tól este 18 óráig) 15000 lux-szal, a kísérlet középső időszakaszában átlagosan 17000 luxszal, majd a kísérlet utolsó szakaszában átlagosan 22000 luxszal világítottuk meg, melyet reggel 5-6, illetve 18-19 óra között 50\%-os fényintenzitással történő megvilágítás egészített ki.

A fent ismertetett vernalizációs folyamat végül nem bizonyult sikeresnek, a növények nem indultak bokrosodásnak, megnyúltak, ezért 2018.07.18-án került sor a hajtások első levágására. A hajtás mintavételt 2018.07.23-án, 2018.07.30-én és 
2018.08.03-án megismételtük. A levágott hajtásokat megmértük, desztillált vízben kétszer megmostuk, majd papírtörölközőre helyezve laboratóriumi asztalon, szobahőmérsékleten előszárítottuk és száradás után papírzacskókba helyeztük. 2018.08.08-án, 08.09-én és 08.10-én zajlott le a tönkölybúzával beállított tenyészedényes kísérlet bontása, a hajtások nedves össztömegének mérése, a levelek desztillált vízben történt mosása, majd elöszárítása laboratóriumi asztalon, szobahőmérsékleten. A tönkölybúza gyökereit csapvízzel és kétszer váltott desztillált vízzel mostuk meg. A gyökerekről papírtörölközővel leitattuk a vizet, majd elektromos táramérleggel megmértuik a nedves tömegét. Laboratóriumi asztalon, szobahőmérsékleten történt elöszárítás után a növénymintákat $70^{\circ} \mathrm{C}$-on 24 órán át szárítószekrényben megszárítottuk, majd visszamértük a szárazanyagot. A száraz növénymintákat elektromos készülékkel ledaráltuk $(<1 \mathrm{~mm})$, pattintással záródó mủanyag tasakokba helyeztük, majd exszikkátorban tároltuk. A tenyészedények bontásakor kevert talajmintákat is vettünk. A talajmintákat müanyag tálcákra terítve szobahőmérsékleten légszáraz állapotig megszárítottuk, majd 25-25 leszúrásból 3-3 párhuzamos mintát alakítottunk ki a kémiai analízishez.

A növény-, talaj- és szennyvízüledék minták elemanalízise a Debreceni Egyetem Agrármüszerközpontjában történt, cc. salétromsav- cc. hidrogén-peroxid 3:1 (v/v) elegyével mikrohullámmal való feltárás után ICP-OES készülékkel 3, ill. 4 ismétléssel.

\section{Eredmények és értékelésük}

\subsection{A növénynevelő közegek jellemzői és elem-összetétele}

A kísérleti kontroll talaj vizes kivonatban mért pH értéke $(7,72)$ a gyengén lúgos tartományba esik. A KCl oldatban mért rejtett savanyúság 7,28-7,34 között változott. A talaj összes sótartalma nem jelentős, átlagosan $0,057 \mathrm{~m} / \mathrm{m} \%$ volt. Az Arany-féle kötöttségi száma alapján a kísérleti talaj fizikai félesége vályog. A talajban a $\mathrm{CaCO}_{3}-$ tartalom 2,13-2,45 m/m \% között alakult. A talaj humusztartalma átlagosan 2,27 $\mathrm{m} / \mathrm{m} \%$ volt.

A kontroll talaj makro- és mezoelem-tartalmát megvizsgálva a foszfor esetében $1122 \mathrm{mg} / \mathrm{kg}$, a káliumnál 1859, a kalciumnál 17921, a magnéziumnál 5055, valamint a vasnál pedig $11799 \mathrm{mg} / \mathrm{kg}$-os értékeket mértünk átlagosan. A kísérleti talaj esszenciális mikroelem összetételét tekintve a bór átlagosan 10,1; a molibdén 0,997, illetve a mangán $306 \mathrm{mg} / \mathrm{kg}$ mennyiségben volt kimutatható. A hazai talajok 10-40 $\mathrm{mg} / \mathrm{kg}$ rezet tartalmaznak (Simon, 2014), az esetünkben mért koncentráció (átlagosan $44,4 \mathrm{mg} / \mathrm{kg}$ ) kissé meghaladta ezt a tartományt. A cink mennyiségét tanulmányozva ismert, hogy a hazai szennyezetlen talajaink $80 \%$-ban $<25-75 \mathrm{mg} / \mathrm{kg}$ cink található (Simon, 2014). Mérési eredményeink alapján kijelenthető, hogy a kísérletbe vont talaj cinktartalma (172-180 mg/kg) az országos átlagnál nagyobb, és a 6/2009. (IV. 14.) KvVM-EüM-FVM együttes rendelet alapján megközelíti a földtani közeg szennyezettségére vonatkozó $200 \mathrm{mg} / \mathrm{kg}$-os szennyezettségi határértéket. A króm mért koncentrációja (111-128 mg/kg) meghaladja, a nikkelé 
(31,2-31,8 mg/kg) megközelíti a fenti rendeletben lefektetett $75 \mathrm{mg} / \mathrm{kg}-\mathrm{os}$, illetve 40 $\mathrm{mg} / \mathrm{kg}$-os határértékeket.

A szennyvízüledék vizes kivonatban mért $\mathrm{pH}$ értéke $(7,11)$ a semleges tartományba esik, az összes sótartalma átlagosan $1,80 \quad \mathrm{~m} / \mathrm{m} \quad \%$ volt. A szennyvízüledékben a $\mathrm{CaCO}_{3}$-tartalom 1,79-1,84 $\mathrm{m} / \mathrm{m} \%$ között változott. A kísérletben alkalmazott szennyvízüledék átlagosan $91,98 \mathrm{~m} / \mathrm{m} \%$ szárazanyagtartalmú és $26,88 \mathrm{~m} / \mathrm{m} \%$ szervesanyag-tartalmú volt. Az „összes” makro- és mezoelem-tartalmat vizsgálva, az alaptalajhoz viszonyítva, foszforból közel ötszörös értéket $(5125 \mathrm{mg} / \mathrm{kg})$ mértünk, mely valószínüleg az elszikkasztott szennyvíz nagy detergens-tartalmára vezethető vissza. Az esszenciális mikroelemek (B-25,0; Mo-1,97, Mn-514 mg/kg) szintén jelentős mennyiségben mutathatók ki a szennyvíz üledékből. A kijuttatott szennyvízüledék a vizsgált toxikus elemeket (As-12,3; $\mathrm{Cd}-1,27 ; \mathrm{Cr}-1027 ; \mathrm{Cu}-189 ; \mathrm{Ni}-49,5 ; \mathrm{Pb}-287 ; \mathrm{Zn}-888 \mathrm{mg} / \mathrm{kg}$ ) jelentős mennyiségben tartalmazta, legkiemelkedőbb értékeket a króm és a cink esetében mértïnk. A Cd, Cr, Cu, Ni, Pb és Zn esetén a mért értékek meghaladták a 6/2009. (IV. 14.) KvVM-EüM-FVM együttes rendeletben a földtani közeg szennyezettségére lefektetett határértékeket. A szennyvízüledék toxikuselemkoncentrációit a kísérleti alaptalaj átlagértékeivel összevetve a króm esetében az üledékben egy nagyságrenddel nagyobb, míg a cink esetén ötször nagyobb értékeket mértünk.

\subsection{A tönkölybúza szerveinek elem-összetétele a tenyészedényes kísérletben}

Az 1-3. táblázatokban a tönkölybúzával beállított tenyészedényes, fényszobás kísérlet növénymintáinak makro-, mezo-, mikroelem- (tápelem), illetve toxikuselem-tartalmát szemléltetjük.

A makroelem-tartalmat illetően megállapíthatjuk, hogy a 10\%-ban kijuttatott Debrecen-Lovászzugi szennyvízüledék a kontroll talajhoz viszonyítva jelentősen megemelte mind a gyökerekben, mind a hajtásokban a felvett foszfor-, kálium-, kalcium-, magnézium-, nátriumkoncentrációkat mindkét tönkölybúza vonal (cv. GK Fehér "A"; cv. GK Fehér "B") esetében. A legtöbb felvett foszfort és káliumot a cv. GK Fehér "A" vonal esetén detektáltuk. A nátrium kivételével a vizsgált makroelemek a tönkölybúza hajtásában voltak nagyobb mennyiségben kimutathatóak (1. táblázat). 
1. táblázat: A tönkölybúzával beállított tenyészedényes, fényszobás kísérlet növénymintáinak makro- és mezoelem-tartalma, $\mathrm{HNO}_{3} / \mathrm{H}_{2} \mathrm{O}_{2}$ feltárásból ICPOES technikával mérve. n=3. (Nyíregyházi Egyetem, 2018.08.08.)

\begin{tabular}{|c|c|c|c|c|c|c|}
\hline \multirow{3}{*}{ Kezelés } & \multirow{3}{*}{ Fajta } & \multicolumn{5}{|c|}{ Makro- és mezoelemek } \\
\hline & & $\mathbf{P}$ & $\mathbf{K}$ & $\mathbf{C a}$ & Mg & $\mathbf{N a}$ \\
\hline & & \multicolumn{5}{|c|}{$\mu \mathrm{g} / \mathrm{g}$} \\
\hline \multicolumn{7}{|c|}{ Gyökér } \\
\hline Kontroll & cv. GK Fehér "A" & 4009 & 19330 & 8579 & 2358 & 4153 \\
\hline 10\% D-Lov. zugi szennyvízüledék & cv. GK Fehér "A" & 4247 & 22547 & 10343 & 2418 & 4651 \\
\hline Kontroll & cv. GK Fehér "B" & 3704 & 17804 & 8786 & 2025 & 5060 \\
\hline \multirow[t]{2}{*}{ 10\% D-Lov. zugi szennyvízüledék } & cv. GK Fehér "B" & 4162 & 19573 & 11712 & 2552 & 5449 \\
\hline & \multicolumn{6}{|c|}{ Hajtás } \\
\hline Kontroll & cv. GK Fehér "A" & 5848 & 54389 & 4591 & 2758 & 957 \\
\hline 10\% D-Lov. zugi szennyvízüledék & cv. GK Fehér "A" & 6259 & 57452 & 5900 & 3136 & 1345 \\
\hline Kontroll & cv. GK Fehér "B" & 5150 & 53151 & 5074 & 2549 & 1460 \\
\hline 10\% D-Lov. zugi szennyvízüledék & cv. GK Fehér "B" & 6010 & 55025 & 5643 & 2754 & 1744 \\
\hline
\end{tabular}

Forrás: A szerzők saját szerkesztése.

Az esszenciális mikroelem-felvétel esetén a gyökérszürö-rendszernek köszönhetően a tönkölybúza hajtásában a gyökérhez képest kevesebb rezet, vasat, mangánt és cinket mértünk. A két tönkölybúza vonal mikroelem-felvételét összehasonlítva megállapíthatjuk, hogy a GK Fehér "A" több vasat, mangánt és cinket vett fel, mint a GK Fehér "B", míg a rézfelvétel az utóbbi vonal esetén volt nagyobb a hajtásokban (2. táblázat).

A tönkölybúza toxikuselem-felvételét elemezve megállapítható, hogy a gyökerekben lényegesen több elem halmozódott fel a hajtásokhoz képest (3. táblázat).

A növényekben felvett esszenciális mikroelemek, illetve toxikus elemek koncentrációja és egymáshoz viszonyított aránya, ill. a gyökerek és hajtásokban való eloszlása nem tért el más kutatók (Adriano, 2001; Babula et al., 2008; KabataPendias, 2004; Kabata-Pendias, 2011; Slepecka et al., 2017; Simon, 2014; Tőzsér, 2018) által korábban megfigyelt, illetve leírt jelenségektöl. 
2. táblázat: A tönkölybúzával beállított tenyészedényes, fényszobás kísérlet növénymintáinak esszenciális mikroelem-tartalma, $\mathrm{HNO}_{3} / \mathrm{H}_{2} \mathrm{O}_{2}$ feltárásból

ICP-OES technikával mérve. n=3. (Nyíregyházi Egyetem, 2018.08.08.)

\begin{tabular}{|c|c|c|c|c|c|}
\hline \multirow{3}{*}{ Kezelés } & \multirow{3}{*}{ Fajta } & \multicolumn{4}{|c|}{$\begin{array}{c}\text { Esszenciális } \\
\text { mikroelemek }\end{array}$} \\
\hline & & $\mathrm{Cu}$ & $\mathbf{F e}$ & Mn & $\mathbf{Z n}$ \\
\hline & & \multicolumn{4}{|c|}{$\mu \mathrm{g} / \mathrm{g}$} \\
\hline & & \multicolumn{4}{|c|}{ Gyökér } \\
\hline & cv. GK Fehér & & & & \\
\hline Kontroll & "A" & 22,4 & 776 & 55,2 & 320 \\
\hline 10\% D-Lov. zugi & cv. GK Fehér & & & & \\
\hline szennyvízüledék & "A" & 30,3 & 1137 & 74,2 & 468 \\
\hline \multirow{6}{*}{$\begin{array}{l}\text { Kontroll } \\
\text { 10\% D-Lov. zugi } \\
\text { szennyvízüledék }\end{array}$} & cv. GK Fehér & & & & \\
\hline & "B" & 21,5 & 880 & 53,6 & 248 \\
\hline & cv. GK Fehér & & & & \\
\hline & "B" & 30,0 & 1236 & 75,7 & 393 \\
\hline & & \multicolumn{4}{|c|}{ Hajtás } \\
\hline & cv. GK Fehér & & & & 64,6 \\
\hline Kontroll & "A" & 7,37 & 124 & 7,73 & 5 \\
\hline 10\% D-Lov. zugi & cv. GK Fehér & & & & 75,2 \\
\hline szennyvízüledék & "A" & 9,61 & 212 & 8,55 & 3 \\
\hline & cv. GK Fehér & & & & 47,8 \\
\hline Kontroll & "B" & 8,46 & 104 & 6,37 & 2 \\
\hline $10 \%$ D-Lov. zugi & cv. GK Fehér & & & & 54,5 \\
\hline szennyvízüledék & "B" & 10,5 & 131 & 7,91 & 0 \\
\hline
\end{tabular}

Forrás: A szerzők saját szerkesztése. 
- 116 Uri Zs. - Simon L. - Vigh Sz. -Vincze Gy. - Irinyiné Oláh K.

3. táblázat: A tönkölybúzával beállított tenyészedényes, fényszobás kísérlet növénymintáinak toxikuselem-tartalma, $\mathrm{HNO}_{3} / \mathrm{H}_{2} \mathrm{O}_{2}$ feltárásból ICP-OES technikával mérve. n=3. (Nyíregyházi Egyetem, 2018.08.08.)

\begin{tabular}{|c|c|c|c|c|c|c|c|}
\hline \multirow{3}{*}{ Kezelés } & \multirow[b]{2}{*}{ Fajta } & \multicolumn{6}{|c|}{ Toxikus elemek } \\
\hline & & As & $\mathbf{B a}$ & $\mathbf{C d}$ & $\mathrm{Cr}$ & $\mathbf{N i}$ & $\mathbf{P b}$ \\
\hline & & \multicolumn{6}{|c|}{$\mu \mathrm{g} / \mathrm{g}$} \\
\hline & & \multicolumn{6}{|c|}{ Gyökér } \\
\hline \multirow{2}{*}{$\begin{array}{l}\text { Kontroll } \\
10 \% \text { D-Lov. zugi } \\
\text { szennyvízüledék }\end{array}$} & cv. GK Fehér "A" & 0,89 & 20,3 & 0,76 & 2,38 & 9,68 & 0,81 \\
\hline & cv. GK Fehér "A" & 1,27 & 24,7 & 1,06 & 4,63 & 16,2 & 1,15 \\
\hline \multirow{3}{*}{$\begin{array}{l}\text { Kontroll } \\
10 \% \text { D-Lov. zugi } \\
\text { szennyvízüledék }\end{array}$} & cv. GK Fehér "B" & 0,80 & 22,7 & 0,89 & 2,84 & 6,04 & 0,77 \\
\hline & GK $\mathrm{H}$ & 6 & 4 & 1,17 & 54 & 11,6 & 77 \\
\hline & & \multicolumn{6}{|c|}{ Hajtás } \\
\hline \multirow{2}{*}{$\begin{array}{l}\text { Kontroll } \\
10 \% \text { D-Lov. zugi } \\
\text { szennyvízüledék }\end{array}$} & cv. GK Fehér "A" & 0,22 & 10,7 & 0,107 & 0,22 & 0,74 & 0,23 \\
\hline & GK Fehér "A" & 0,34 & 13,6 & 0,1 & & 1,27 & 45 \\
\hline \multirow{3}{*}{$\begin{array}{l}\text { Kontroll } \\
\text { 10\% D-Lov. zugi } \\
\text { szennyvízüledék }\end{array}$} & cv. GK Fehér "B" & 0,23 & 9,07 & 0,174 & 0,22 & 1,66 & 0,21 \\
\hline & & & & & & & \\
\hline & cv. GK Fehér "B" & 0,28 & 13,5 & 0,215 & 0,25 & 2,24 & 0,28 \\
\hline
\end{tabular}

Forrás: A szerzők saját szerkesztése.

\subsection{A tönkölybúza talajának elemösszetétele a tenyészedényes kísérletben}

A 4-6. táblázatokban mutatjuk be a tönkölybúzával beállított tenyészedényes, fényszobás kísérlet növénynevelő közegeinek (talaj, talaj+szennyvízüledék keverék) makro-, mezo-, esszenciális mikroelem- és toxikuselem-tartalmát a növénynevelés befejezésekor.

4. táblázat: A tönkölybúzával beállított tenyészedényes, fényszobás kísérlet talajának makro- és mezoelem-tartalma a növénynevelés befejezésekor, ICPOES technikával mérve. $n=4$. (Nyíregyházi Egyetem, 2018.08.08.)

\begin{tabular}{|c|c|c|c|c|c|c|c|}
\hline \multirow{3}{*}{ Kezelés } & \multirow{3}{*}{ Fajta } & \multicolumn{6}{|c|}{ Makro- és mezoelemek } \\
\hline & & $\mathbf{P}$ & $\mathbf{K}$ & $\mathbf{C a}$ & Mg & $\mathbf{F e}$ & $\mathrm{Na}$ \\
\hline & & \multicolumn{6}{|c|}{$\mathrm{mg} / \mathrm{kg}$} \\
\hline Kontroll & $\begin{array}{ll}\text { cv. GK Fehér } \\
\text { DH "A" }\end{array}$ & 1212 & $\begin{array}{c}205 \\
5\end{array}$ & $\begin{array}{c}1759 \\
7\end{array}$ & $\begin{array}{c}500 \\
9\end{array}$ & $\begin{array}{c}1319 \\
9\end{array}$ & 339 \\
\hline $\begin{array}{l}\text { 10\% Debrecen-lovász-zugi } \\
\text { szennyvízüledék }\end{array}$ & $\begin{array}{l}\text { cv. GK Fehér } \\
\text { DH "A" }\end{array}$ & 1485 & $\begin{array}{c}217 \\
5\end{array}$ & $\begin{array}{c}2036 \\
6\end{array}$ & $\begin{array}{c}524 \\
9\end{array}$ & $\begin{array}{c}1378 \\
1\end{array}$ & 353 \\
\hline Kont & $\begin{array}{l}\text { cv. GK Fehér } \\
\text { DH "B" }\end{array}$ & 1351 & $\begin{array}{c}223 \\
0\end{array}$ & $\begin{array}{c}1862 \\
2\end{array}$ & $\begin{array}{c}526 \\
7\end{array}$ & $\begin{array}{c}1349 \\
1\end{array}$ & 351 \\
\hline $\begin{array}{l}\text { 10\% Debrecen-lovász-zugi } \\
\text { szennyvízüledék }\end{array}$ & $\begin{array}{l}\text { cv. GK Fehér } \\
\text { DH "B" }\end{array}$ & 1538 & $\begin{array}{c}235 \\
6\end{array}$ & $\begin{array}{c}2041 \\
3\end{array}$ & $\begin{array}{c}537 \\
0\end{array}$ & $\begin{array}{c}1429 \\
1 \\
\end{array}$ & 393 \\
\hline
\end{tabular}

Forrás: A szerzők saját szerkesztése. 
5. táblázat: A tönkölybúzával beállított tenyészedényes, fényszobás kísérlet talajának esszenciális mikroelem-tartalma a növénynevelés befejezésekor, ICP-OES technikával mérve. n=4. (Nyíregyházi Egyetem, 2018.08.08.)

\begin{tabular}{lllcc}
\hline \multirow{2}{*}{ Kezelés } & \multicolumn{2}{c}{ Fajta } & \multicolumn{3}{c}{ Esszenciális mikroelemek } \\
\cline { 3 - 5 } & & Cu & Mn & Zn \\
\cline { 3 - 5 } & & \multicolumn{3}{c}{$\mathrm{mg} / \mathrm{kg}$} \\
\hline Kontroll & cv. GK Fehér DH "A" & 45,34 & 299 & 149 \\
Kezelt & cv. GK Fehér DH "A" & 62,31 & 315 & 271 \\
Kontroll & cv. GK Fehér DH "B" & 47,71 & 311 & 163 \\
Kezelt & cv. GK Fehér DH "B" & 63,25 & 317 & 281 \\
\hline
\end{tabular}

Forrás: A szerzők saját szerkesztése.

6. táblázat: A tönkölybúzával beállított tenyészedényes, fényszobás kísérlet talajának toxikuselem-tartalma a növénynevelés befejezésekor, ICP-OES technikával mérve. n=4. (Nyíregyházi Egyetem, 2018.08.08.)

\begin{tabular}{|c|c|c|c|c|c|c|c|}
\hline \multirow{3}{*}{ Kezelés } & \multirow{3}{*}{ Fajta } & \multicolumn{6}{|c|}{ Toxikus elemek } \\
\hline & & As & $\mathbf{B a}$ & Cd & $\mathrm{Cr}$ & $\mathbf{N i}$ & $\mathbf{P b}$ \\
\hline & & \multicolumn{6}{|c|}{$\mathrm{mg} / \mathrm{kg}$} \\
\hline Kontroll & cv. GH Fehér DH "A" & 7,94 & 115 & 0,267 & 140 & 22,13 & 25,62 \\
\hline Kezelt & cv. GH Fehér DH "A" & 10,91 & 159 & 0,310 & 288 & 29,47 & 48,26 \\
\hline Kontroll & cv. GH Fehér DH "B" & 7,97 & 120 & 0,267 & 154 & 24,53 & 29,71 \\
\hline Kezelt & cv. GH Fehér DH "B" & 11,24 & 162 & 0,301 & 318 & 30,00 & 49,67 \\
\hline
\end{tabular}

Forrás: A szerzők saját szerkesztése.

Az adatokból nyilvánvaló, hogy az alaptalajba kijuttatott szennyvízüledék kisebb-nagyobb mértékben megemelte a tápelemek, illetve toxikus elemek koncentrációit a növénynevelö közegekben, mindkét kísérletbe bevont tönkölybúza vonal esetén. A legnyilvánvalóbb, több mint 200\%-os emelkedést a króm esetén figyelhettük meg, jelentős volt továbbá az ólom $(+67 \ldots+90 \%)$, illetve a cink $(+70 \ldots+80 \%)$ koncentrációjának megemelkedése a növénynevelö közegekben a szennyvízüledék kijuttatása miatt.

\section{Következtetések}

Fényszobás tenyészedényes kísérletünk alapján megállapítottuk, hogy a toxikus elemekkel enyhén szennyezett alaptalajba kijuttatott, tápelemekben gazdag és krómmal, cinkkel erősen szennyezett szennyvízüledék mindkét megvizsgált tönkölybúza vonalban, a gyökerekben és hajtásokban egyaránt, megemelte a létfontosságú makroelemek $(\mathrm{P}, \mathrm{K}, \mathrm{Ca}, \mathrm{Mg})$ és az esszenciális mikroelemek $(\mathrm{Cu}, \mathrm{Fe}$, $\mathrm{Mn}, \mathrm{Zn}$ ) koncentrációit. A toxikus elemekből (As, $\mathrm{Ba}, \mathrm{Cd}, \mathrm{Cr}, \mathrm{Ni}, \mathrm{Pb}$ ) - mindkét tönkölybúza vonalban - a gyökerekben lényegesen több halmozódott fel a 
hajtásokhoz képest, és a kijuttatott szennyvízüledék valamennyi toxikus elem koncentrációját jelentősen megnövelte a kontroll kultúrákhoz viszonyítva, mind a gyökerekben, mind a hajtásokban. Az elemösszetétel alapján nem tudtuk igazolni, hogy a nemesítők által szenzitívebbnek feltételezett GK Fehér tönkölybúza fajta „A” vonala érzékenyebben reagál a toxikuselem-szennyezés okozta stresszre, illetve több toxikus elemet vesz fel, mint a toleránsabbnak tekintett „B” vonal.

\section{Köszönetnyilvánítás}

A kutatómunkát a GINOP 2.2.1-15-2017-00042 „K+F versenyképességi és kiválósági együttmüködések” program keretén belül „A Pannon régió növényeinek genetikai hasznosítása” c. pályázat támogatta. Köszönjük Dr. Bóna Lajosnak (Gabonakutató Nonprofit Kft., Szeged), hogy a tönkölybúza vonalak szaporítóanyagát rendelkezésünkre bocsátotta. Köszönjük Dr. Pusztahelyi Tündének és munkatársainak (Debreceni Egyetem Agrármüszerközpont), hogy a minták kémiai analízisét elvégezték. Köszönjük Dr. Magura Tibornak és munkatársainak, hogy a Debrecen lovász-zugi kísérleti helyszínt biztosították.

\section{Irodalomjegyzék}

6/2009. (IV. 14.) KvVM-EüM-FVM együttes rendelet a földtani közeg és a felszín alatti víz szennyezésselszembeni védelméhez szükséges határértékekről és a szennyezések méréséről.

Adriano D. C. (2001): Trace Elements in Terrestrial Environments: Biogeochemistry, Bioavailability and Risks of Metals. Springer, New York. 1-867.

Alloway B. J. (2013): Sources of heavy metals and metalloids in soils. In: Alloway B. J. (szerk.): Heavy Metals in Soils. Trace Metals and Metalloids in Soils and their Bioavailability. Springer Science+Business Media, Dordrecht. 11-50.

Babula P., Adam V., Opatrilova R., Zehnalek J., Havel L., Kizek R. (2008): Uncommon heavy metals, metalloids and their plant toxicity: a review. Environmental Chemistry Letters, 6 (4): 189-213.

Kabata-Pendias A. (2004): Soil-plant transfer of trace elements - an environmental issue. Geoderma, 122 (2-4): 143-149.

Kabata-Pendias A. (2011): Trace Elements in Soils and Plants. Negyedik kiadás. CRC Press, Boca Raton, FL. Taylor \& Francis Group. 1-520.

Kabata-Pendias A., Mukherjee A. B. (2007). Trace Elements from Soil to Human. Springer, Berlin, Heidelberg, New York. 1-550.

Simon L. (2014): Potentially harmful elements in agricultural soils. In: Bini, C., Bech, J. (szerk.), PHEs, Environment and Human Health. Potentially Harmful Elements in the Environment and the Impact on Human Health. Springer, Dordrecht, Heidelberg, New York, London. 85-137, 142-150.

Slepecka K., Kalwa K., Wyrostek J., Pankiewicz U. (2017): Evaluation of cadmium, lead, zinc and copper levels in selected ecological cereal food products and their non-ecological counterparts. Current Issues in Pharmacy and Medical Sciences, 30 (3): 147-150.

Tőzsér D. (2018): Nehézfémekkel szennyezett talajok fitoremediációjának vizsgálata. PhD értekezés, Juhász-Nagy Pál Doktori Iskola, Debreceni Egyetem. 1-148. 